\title{
Вмј Global Health Finding the missing millions: lessons from 10 active case finding interventions in high tuberculosis burden countries
}

Tripti Pande (D , ${ }^{1}$ Nathaly Aguilera Vasquez, ${ }^{1}$ Danielle Cazabon, ${ }^{2}$ Jacob Creswell, ${ }^{3}$ Miranda Brouwer, ${ }^{4}$ Oriol Ramis, ${ }^{5}$ Robert Hartley Stevens, ${ }^{6}$ Ramya Ananthakrishnan, ${ }^{7}$ Shahina Qayyum, ${ }^{8}$ Chukwuka Alphonsus, ${ }^{9}$ Charity Oga-Omenka, ${ }^{1}$ Vaidehi Nafade, ${ }^{2}$ Paulami Sen, ${ }^{2}$ Madhukar Pai (D) 2,10

To cite: Pande T, Vasquez NA, Cazabon D, et al. Finding the missing millions: lessons from 10 active case finding interventions in high tuberculosis burden countries. BMJ Global Health 2020;5:e003835. doi:10.1136/ bmjgh-2020-003835

Handling editor Seye Abimbola

TP and NAV contributed equally.

Received 28 August 2020

Revised 28 November 2020

Accepted 3 December 2020

Check for updates

(c) Author(s) (or their employer(s)) 2020. Re-use permitted under CC BY-NC. No commercial re-use. See rights and permissions. Published by BMJ.

For numbered affiliations see end of article.

Correspondence to

Tripti Pande;

tripti.pande@mail.mcgill.ca

\section{INTRODUCTION}

In 2019, 10.0 million people developed tuberculosis (TB) yet 2.9 million were not notified to National TB programmes (NTPs). ${ }^{1}$ This is largely due to limited accessibility to healthcare services, underdeveloped health reporting systems, insufficient human resources and poor linkages between private providers and national authorities. ${ }^{2}$ There are various global initiatives to address this challenge, including the Find.Treat.All \#EndTB initiative and the End TB strategy which aims to reduce TB incidence by $90 \%$ between 2015 and $2035 .^{3}$

To support innovative programmes, approaches and technologies aiming to increase the number of people detected with TB in low-and-middle income countries (LMICs), the TB REACH initiative was launched in 2010. It is led by the Stop TB Partnership and primarily funded by the Government of Canada. ${ }^{4}$ Active case finding (ACF) interventions are the most commonly funded TB REACH interventions and refer to screening that occurs outside of the healthcare system where individuals with TB-like symptoms are identified and referred for TB diagnosis. This differs from common practices where the patient seeks diagnosis at a health facility (ie, passive case finding). ${ }^{5}$

While there have been various evaluations on the effectiveness of the ACF interventions in many LMICs such as India, Nigeria and Cameroon, ${ }^{6-8}$ lessons learnt from implementation experiences are often constrained to internal meetings or annual reports. This limits sharing of valuable lessons learnt across multiple settings and among implementors which could be leveraged in the planning and implementation of new ACF interventions.

\section{Summary box}

In 2019, 2.9 million people with tuberculosis (TB) were not notified to National TB Programmes due to limited accessibility, underdeveloped health reporting systems and linkages between public and private sectors as well as lack of human resources.

- With the emphasis on finding the missing cases ('missing millions') of TB, the TB REACH initiative launched in 2010, has funded various active case finding interventions (ACF) between 2010 and 2019 in multiple low-and-middle income countries.

- To gain a holistic perspective on lessons learnt, we discussed with 10 TB REACH-funded implementors, monitoring and evaluation consultants and members of the TB REACH secretariat.

- Three sets of lessons learnt were identified; addressing barriers (physical, social), project management (staff motivation, data driven decisions) and stakeholder management.

- This led to three main recommendations to assist future ACF implementors:

- Forge partnerships with local and national (ie, government institutions) stakeholders to ensure sustainability and scalability.

- Ensure thorough management of the intervention/programme by consistently overseeing budget, motivating and educating staff as well as making data-driven decisions.

- Capitalise on contextual knowledge (ie, hiring local, collaborating with existing partners in the community) as well as previous implementation experience.

With the push to find the missing millions, we discussed lessons learnt with 10 implementors funded by the TB REACH initiative, each targeting different populations (ie, children, transgender communities, rural communities) across a wide range of settings and countries (table 1). Further, to provide a holistic view, we also incorporated the perspectives 


\begin{tabular}{|c|c|c|c|c|}
\hline Country & Year & $\begin{array}{l}\text { Organisation } \\
\text { category }\end{array}$ & Intervention type* & Intervention \\
\hline Afghanistan & $\begin{array}{l}2017- \\
2018\end{array}$ & $\begin{array}{l}\text { Non- } \\
\text { governmental } \\
\text { organisation }\end{array}$ & Community outreach & $\begin{array}{l}\text { School girls were trained to screen women and girls in rural villages. } \\
\text { Also, health workers (doctors, midwives, nurses) screened women and } \\
\text { young girls attending clinics. }\end{array}$ \\
\hline Ethiopia & $\begin{array}{l}2013- \\
2015\end{array}$ & $\begin{array}{l}\text { Academic } \\
\text { institution }\end{array}$ & Community outreach & $\begin{array}{l}\text { Health extension workers conducted house-to-house screening among } \\
\text { adults and contact tracing was also conducted. Isoniazid Preventative } \\
\text { Therapy (IPT) was initiated for asymptomatic children. }\end{array}$ \\
\hline India & $\begin{array}{l}2017- \\
2019\end{array}$ & $\begin{array}{l}\text { Non- } \\
\text { governmental } \\
\text { organisation }\end{array}$ & $\begin{array}{l}\text { Systematic } \\
\text { screening, } \\
\text { community outreach, } \\
\text { contact tracing }\end{array}$ & $\begin{array}{l}\text { Healthcare workers screened individuals for TB in outpatient } \\
\text { departments, and pharmacies and conducted contact tracing at home } \\
\text { among contacts of people with TB. }\end{array}$ \\
\hline Kenya & $\begin{array}{l}2010- \\
2012\end{array}$ & $\begin{array}{l}\text { Non- } \\
\text { governmental } \\
\text { organisation }\end{array}$ & $\begin{array}{l}\text { Contact tracing, key } \\
\text { populations }\end{array}$ & $\begin{array}{l}\text { Recruited and trained community health workers to conduct door-to- } \\
\text { door TB and HIV screening, and contact tracing among contacts of } \\
\text { people with TB. }\end{array}$ \\
\hline Nepal & $\begin{array}{l}2014- \\
2016\end{array}$ & $\begin{array}{l}\text { Non- } \\
\text { governmental } \\
\text { organisation }\end{array}$ & $\begin{array}{l}\text { Systematic } \\
\text { screening, } \\
\text { community outreach }\end{array}$ & $\begin{array}{l}\text { Conducted chest camps for community based screening of children } \\
\text { and people living in slums. }\end{array}$ \\
\hline Nigeria & $\begin{array}{l}2013- \\
2014\end{array}$ & $\begin{array}{l}\text { Non- } \\
\text { governmental } \\
\text { organisation }\end{array}$ & Key populations & $\begin{array}{l}\text { Using health workers to screen children for TB at primary schools and } \\
\text { contacts of people with TB, at anti-retroviral treatment clinics. }\end{array}$ \\
\hline Pakistan & $\begin{array}{l}2018- \\
2019\end{array}$ & $\begin{array}{l}\text { Academic } \\
\text { institution }\end{array}$ & Key populations & $\begin{array}{l}\text { Outreach workers recruited and trained by the project conducted } \\
\text { house-to-house screening or work place screening among transgender } \\
\text { populations. }\end{array}$ \\
\hline Pakistan & $\begin{array}{l}2014- \\
2016\end{array}$ & $\begin{array}{l}\text { Non- } \\
\text { governmental } \\
\text { organisation }\end{array}$ & $\begin{array}{l}\text { Community } \\
\text { outreach, contact } \\
\text { tracing, key } \\
\text { populations }\end{array}$ & $\begin{array}{l}\text { Engaged community screeners to screen households and contacts of } \\
\text { people with TB. They were also responsible for sputum collection, case } \\
\text { detection and follow-up with people with TB. }\end{array}$ \\
\hline Peru & $\begin{array}{l}2017- \\
2018\end{array}$ & $\begin{array}{l}\text { Non- } \\
\text { governmental } \\
\text { organisation }\end{array}$ & Community outreach & $\begin{array}{l}\text { Individuals who formerly had TB screened individuals for TB within their } \\
\text { communities. }\end{array}$ \\
\hline South Africa & $\begin{array}{l}2013- \\
2014\end{array}$ & $\begin{array}{l}\text { Non- } \\
\text { governmental } \\
\text { organisation }\end{array}$ & $\begin{array}{l}\text { Community } \\
\text { outreach, key } \\
\text { population }\end{array}$ & $\begin{array}{l}\text { Engaged community health workers and health workers to conduct } \\
\text { household screening for TB and contact tracing. }\end{array}$ \\
\hline
\end{tabular}

${ }^{*}$ Community outreach=conducting house to house screening within the community or mass screening events; contact tracing=screening contacts of people who had TB; systematic screening=screening a particular targeted population; key populations=those identified as vulnerable or targeted populations within the respective country/region.

ACF, active case finding interventions; TB, tuberculosis.

of monitoring and evaluation (M\&E) consultants and members of the TB REACH secretariat who are key stakeholders in the TB REACH initiative.

Below, we summarise three sets of lessons learnt and three overarching recommendations with the aim of facilitating planning and implementation of future ACF interventions (figure 1).

\section{LESSON 1: ADDRESSING BARRIERS}

ACF largely focuses on marginalised populations who often reside in resource-constrained settings. This poses a major barrier to implementation due to lack of trained staff, improper infrastructure for diagnostic testing and a high workload with limited budgets. For example, in a hard-to-reach area of Nigeria there were initial difficulties in setting up efficient transportation systems for sputum samples as this was not previously in place. In a private sector setting of India, there were difficulties in reading paediatric chest X-rays as this task was often performed by radiologists. Lack of trained staff is not related to limited man power, but is also a result of insufficient budget allocations. Various projects are unable to hire trained staff due to limited funding and lower staff salaries.

Physical accessibility is equally a challenge due to factors such as difficult geographical terrains. This includes unpaved roads to remote areas, lack of mobile networks to establish follow-up with individuals diagnosed with TB or security concerns for health workers in a specific area of a country. These factors were largely prevalent in our conversations with implementors from Nigeria, Pakistan, Afghanistan and Peru.

In addition to physical accessibility, poor acceptability of the intervention in the social setting is another major factor. Due to stigmatisation of certain groups or populations, there are difficulties in hiring staff for project work. For example, in Pakistan, a project working with 


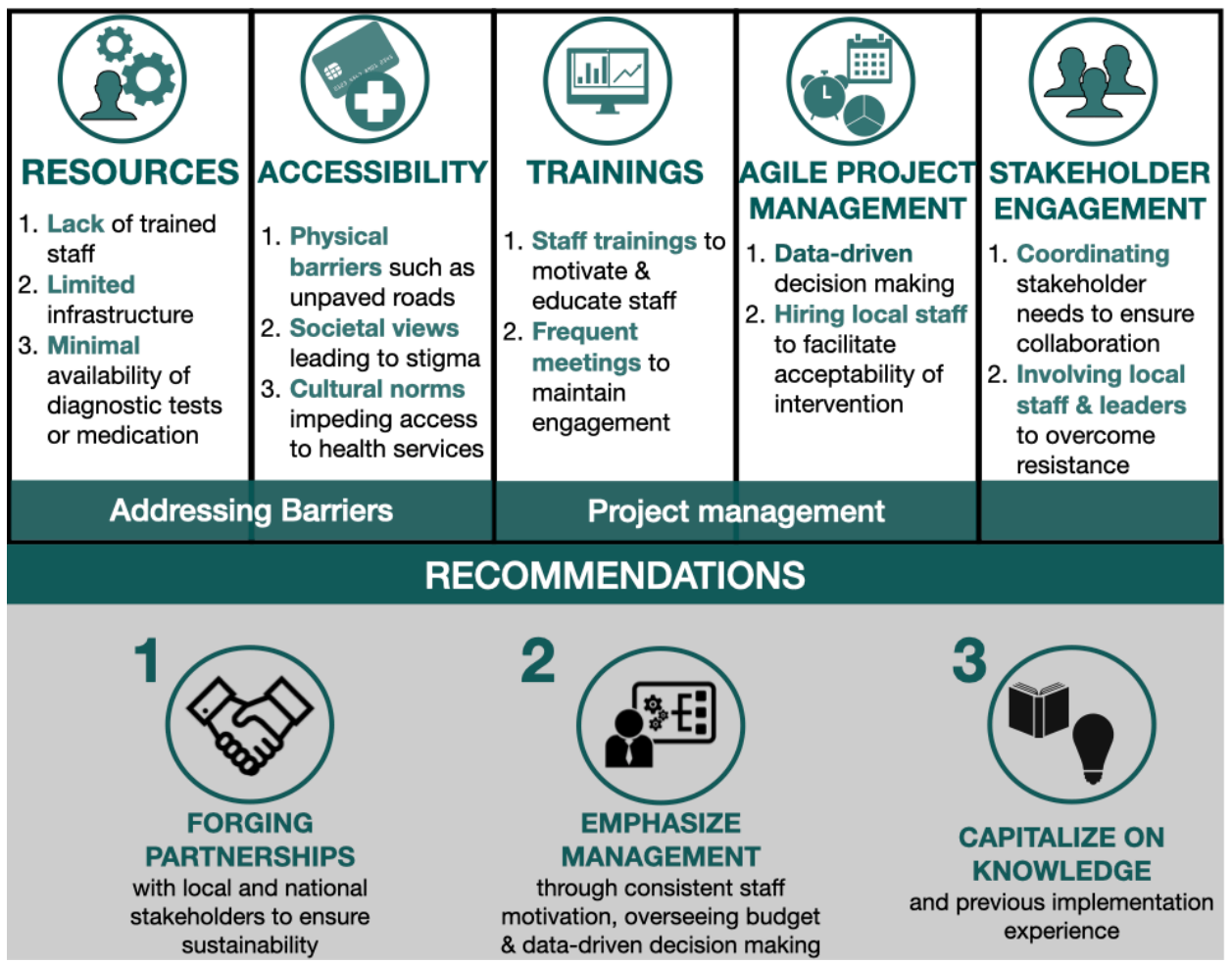

Figure 1 Three lessons learnt from 10 active case finding interventions and emerging recommendations.

a transgender population indicated that the project staff was initially reluctant to perform activities within this population. This was later mitigated through trainings, and education which sensitised the staff members as well as enabled initiation of project activities.

Previously documented successful ACF projects have overcome these issues by hiring local field staff, who live within the communities. ${ }^{6-12}$ Also, leveraging preexisting systems and/or communities to assist with implementation in hard-to-reach areas and encouraging sustainability by strengthening current health systems and health infrastructure. ${ }^{13} 14$ For example, using renewable energy such as solar power to power facilities lacking electricity in rural areas. ${ }^{15}$

\section{LESSON 2: PROJECT MANAGEMENT}

Implementing project management skills enables ACF implementors to not only ensure execution of activities in the field, but to also recognise the need for an agile working environment where data-driven decisionmaking assists in risk mitigation and conflict management. Further, this is well appreciated from M\&E and TB REACH secretariat perspectives. Best practices to project management are notable requirements, from all stakeholders, to a project's success.

Education and raising awareness about $\mathrm{TB}$ is not only relevant for the target population where the ACF intervention is taking place, but equally as important for the project staff. Reportedly, project staff motivation can be sustained by continued trainings, education modules and/or frequent team meetings. This was not only conducive to a positive working environment, but also promoted project success. Hiring local project staff from the targeted community or population was also mentioned as a strong facilitator due to their understanding of the existing infrasctructure and dynamics within the community. Further, hiring staff with previous experience in $\mathrm{TB}$ or ACF interventions also facilitated project implementation. This may not only assist in developing novel ideas for implementation but may also assist in developing partnerships and/or leveraging existing partnerships in the area. An in-depth understanding of the local context as well as the TB context is preferable when initiating ACF interventions.

The key to project management is the ability to adapt quickly to challenges and/or barriers in implementation, also known as agile project management. The latter encourages data-driven decision making to allow ACF activities to continue despite complications, such as lack of electricity to conduct diagnostic tests. For example, in a hard-to-reach area in Nigeria, the implementor encouraged the use of renewable and pre-existing resources such as solar-power in order to ensure a continuous power source for laboratory facilities. This has been previously highlighted as a solution in other contexts. ${ }^{15}$

Regarding data-driven decision making, the use of monthly reports of impact indicators allowed for detection of discrepancies followed by the required adjustments. For example, it was noticed that children with presumptive TB were not reaching diagnostic services because their parents could not afford transportation costs; therefore, the respective project began supporting 
the transportation of children, decreasing the prediagnostic lost to follow-up (LTFU). ACF interventions taking place among populations with large religious beliefs engaged with religious leaders to educate the population about TB. Other interventions used technology such as WhatsApp or other messaging devices to send messages of awareness. Community meetings held by village leaders are also an excellent method to raise awareness about TB and/or the intervention.

These examples highlight the effectiveness of using an agile strategy of adapting to a changing environment and overcoming barriers. This is echoed by a previous successful intervention among tribal populations in India where the programme modified its original scope to include community-based sputum collection (ie, at home) to reduce LTFU between referral and diagnosis. ${ }^{6}$

\section{LESSON 3: STAKEHOLDER ENGAGEMENT}

Stakeholder engagement is a large influencing factor to project implementation as it presented as both a barrier and a facilitator. Coordinating engagement meetings with various stakeholders such as local government staff, facility managers, laboratory technicians, community members and external organisations are extremely important to initiate a project. However, they present with barriers related to transportation, availability, competing priorities and establishing roles/responsibilities. Yet, the importance and necessity of nurturing strong partnerships with project stakeholders and communities is largely emphasised.

Such engagement may assist in avoiding reluctance of engagement from certain stakeholders such as private providers or laboratories. Interventions that had strong partnerships with the NTP and laboratories as well as linkages to the private sector were the most successful. Further, stakeholder engagement facilitates buy-in from community members, particularly in communities with strong cultural or religious beliefs concerning the involvement of women and girls in healthcare seeking practices or as community health volunteers.

Overall, early involvement of all levels of government (national and local), technical working groups and community stakeholders (ie, religious leaders) is imperative in enabling success as well as encouraging sustainability of the intervention. Participatory approaches involving communities in ACF interventions have been noted as a facilitator in previous ACF studies as well as in a ACF field-guide published by the Stop TB Partnership. ${ }^{16} 17$

\section{RECOMMENDATIONS}

Given the alignment of lessons learnt among all M\&E consultants, the TB REACH secretariat and 10 implementors, irrespective of the country or population where their ACF intervention was implemented, there are three main recommendations which arise from our discussions:
1. Forge partnerships with local and national (ie, government institutions) stakeholders to ensure sustainability and scalability.

2. Ensure thorough management of the intervention/ programme by consistently overseeing budget, motivating and educating staff as well as making datadriven decisions.

3. Capitalise on contextual knowledge (ie, hiring local, collaborating with existing partners in the community) as well as previous implementation experience.

To gather detailed examples from each context and encourage learning among ACF implementors working in different settings, further dissemination of lessons learnt should be encouraged. Future ACF implementors are called on to consider the three major sets of lessons learnt and recommendations presented in this article prior to and during ACF implementation. Through collaborative, peer-to-peer learning, we may be able to reach the End TB targets of finding the missing millions and reducing TB incidence by $90 \%$ by 2035 .

\section{Author affiliations}

${ }^{1}$ McGill University Health Centre, Montreal, Québec, Canada

${ }^{2}$ Epidemiology and Biostatistics, McGill University, Montreal, Québec, Canada

${ }^{3}$ Stop TB Partnership, Geneva, Switzerland

${ }^{4}$ PHTB Consultant, Tilburg, The Netherlands

${ }^{5}$ Independent Consultant, Barcelona, Spain

${ }^{6}$ Independent Consultant, Manchester, UK

${ }^{7}$ Resource group for Education and Advocacy for Community Health (REACH), Chennai, India

${ }^{8}$ Bridge Consultants Foundation, Karachi, Pakistan

${ }^{9}$ German Leprosy \& Tuberculosis Relief Association, Enugu, Nigeria

${ }^{10}$ Manipal McGill Program in Infectious Diseases, Manipal Academy of Higher Education, Manipal, India

Twitter Tripti Pande @tripti_pande, Oriol Ramis @epirusconsultor and Madhukar Pai @paimadhu

Acknowledgements The authors would like to thank members of Pai TB Group (MK, SH, EM, AS) for their assistance in transcribing implementor interviews. The authors would also like to thank all grantee organisations, and M\&E consultants who participated in the discussions.

Contributors TP and NAV contributed equally to this paper. TP, DC and MP conceptualised and designed the research study. $\mathrm{CO}-0$, VN and TP conducted interviews for data collection. TP, NAV and PS summarised the discussions and all authors contributed in manuscript writing.

Funding The Research Institute of McGill University Health Centre is a recipient of a knowledge management grant from the TB REACH initiative.

Competing interests TP, NAV and MP are members of the Research Institute of the McGill University Health Center which is a recipient of a knowledge management grant from the TB REACH initiative. RA, SQ and CA received active case finding implementation grants from the TB REACH initiative. OR, MB and RHS are monitoring and evaluation consultants for the TB REACH initiative. JC is a member of the Stop TB Partnership-TB REACH initiative.

Patient consent for publication Not required.

Provenance and peer review Not commissioned; externally peer reviewed.

Data availability statement All data relevant to the analysis are presented in the article.

Open access This is an open access article distributed in accordance with the Creative Commons Attribution Non Commercial (CC BY-NC 4.0) license, which permits others to distribute, remix, adapt, build upon this work non-commercially, and license their derivative works on different terms, provided the original work is properly cited, appropriate credit is given, any changes made indicated, and the use is non-commercial. See: http://creativecommons.org/licenses/by-nc/4.0/. 
ORCID iDs

Tripti Pande http://orcid.org/0000-0002-3552-9604

Madhukar Pai http://orcid.org/0000-0003-3667-4536

\section{REFERENCES}

1 World Health Organization. Global tuberculosis report, 2020. Available: https://www.who.int/publications/i/item/9789240013131

2 World Health Organization. Joint Initiative "FIND.TREAT. ALL.\#ENDTB", 2018. Available: https://www.who.int/tb/jointinitiative/en/

3 World Health Organization. The end TB strategy. global strategy and targets for tuberculosis prevention, care and control after 2015. World Health Organization, 2014.

4 Stop TB Partnership. About TB reach Geneva, 2019. Available: http://stoptb.org/global/awards/tbreach/about.asp

5 World Health Organization. Systematic screening for active tuberculosis: principles and recommendations, 2013.

6 Vyas A, Creswell J, Codlin AJ, et al. Community-based active casefinding to reach the most vulnerable: tuberculosis in tribal areas of India. Int J Tuberc Lung Dis 2019;23:750-5.

7 Oshi DC, Omeje JC, Oshi SN, et al. An evaluation of innovative community-based approaches and systematic tuberculosis screening to improve tuberculosis case detection in Ebonyi state, Nigeria. Int J Mycobacteriol 2017;6:246.

8 Sander MS, Laah SN, Titahong CN, et al. Systematic screening for tuberculosis among hospital outpatients in Cameroon: the role of screening and testing algorithms to improve case detection. J Clin Tuberc Other Mycobact Dis 2019;15:100095.
9 André E, Rusumba O, Evans CA, et al. Patient-led active tuberculosis case-finding in the Democratic Republic of the Congo. Bull World Health Organ 2018;96:522-30.

10 Datiko DG, Lindtjørn B. Health extension workers improve tuberculosis case detection and treatment success in southern Ethiopia: a community randomized trial. PLoS One 2009;4:e5443.

11 Datiko DG, Yassin MA, Theobald SJ, et al. Health extension workers improve tuberculosis case finding and treatment outcome in Ethiopia: a large-scale implementation study. BMJ Glob Health 2017;2:e000390.

12 Merid Y, Mulate YW, Hailu M, et al. Population-based screening for pulmonary tuberculosis utilizing community health workers in Ethiopia. Int J Infect Dis 2019;89:122-7.

13 Teo AKJ, Prem K, Tuot S, et al. Mobilising community networks for early identification of tuberculosis and treatment initiation in Cambodia: an evaluation of a seed-and-recruit model. ERJ Open Res 2020;6:00368-2019.

14 Global Fund. The global fund strategy 2017-2022: investing to end epidemics, 2017.

15 United Nations Development Programme (UNDP). Solar panels improve health care in rural Zambia, 2015. Available: https://www. undp.org/content/undp/en/home/presscenter/articles/2015/09/24/ running-health-facilities-on-solar-panels-in-remote-rural-zambia0. html [Accessed 9 Jun 2020].

16 John S, Gidado M, Dahiru T, et al. Tuberculosis among nomads in Adamawa, Nigeria: outcomes from two years of active case finding. Int J Tuberc Lung Dis 2015;19:463-8.

17 TB Europe Coalition. Engaging religious leaders in TB advocacy: experience of the initiative for health Foundation in Sofia, 2019. 